\title{
Author Correction: Anchoring cortical granules in the cortex ensures trafficking to the plasma membrane for post-fertilization exocytosis
}

\author{
Edgar-John Vogt ${ }^{1,5}$, Keizo Tokuhiro ${ }^{1,6}$, Min Guo (1) 2 , Ryan Dale ${ }^{1,7}$, Guanghui Yang ${ }^{1}$, Seung-Wook Shin 1 , \\ Maria Jimenez Movilla (i) ${ }^{3}$, Hari Shroff ${ }^{2,4} \&$ Jurrien Dean (1) ${ }^{1}$
}

Correction to: Nature Communications https://doi.org/10.1038/s41467-019-10171-7, published online 22 May 2019.

The original version of this Article omitted from the author list, the sixth author Seung-Wook Shin, who is from the 'Laboratory of Cellular and Developmental Biology, NIDDK, National Institutes of Health, Bethesda, MD 20892, USA.' In addition, the following was added to the Author contributions: 'S.W.S. performed an immunoblot.' This has been corrected in both the PDF and HTML versions of the Article.

Published online: 27 June 2019

\begin{abstract}
(c) Open Access This article is licensed under a Creative Commons Attribution 4.0 International License, which permits use, sharing, adaptation, distribution and reproduction in any medium or format, as long as you give appropriate credit to the original author(s) and the source, provide a link to the Creative Commons license, and indicate if changes were made. The images or other third party material in this article are included in the article's Creative Commons license, unless indicated otherwise in a credit line to the material. If material is not included in the article's Creative Commons license and your intended use is not permitted by statutory regulation or exceeds the permitted use, you will need to obtain permission directly from the copyright holder. To view a copy of this license, visit http://creativecommons.org/licenses/by/4.0/.
\end{abstract}

(c) The Author(s) 2019

\footnotetext{
${ }^{1}$ Laboratory of Cellular and Developmental Biology, NIDDK, National Institutes of Health, Bethesda, MD 20892, USA. ${ }^{2}$ Section on High Resolution Optical Imaging, NIBIB, National Institutes of Health, Bethesda, MD 20892, USA. ${ }^{3}$ Department of Cell Biology and Histology, Medical School, University of Murcia, IMIB, 30100 Murcia, Spain. ${ }^{4}$ Advanced Imaging and Microscopy Resource, National Institutes of Health, Bethesda, MD 20892, USA. ${ }^{5}$ Present address: Charité - Universitätsmedizin Berlin, Augustenburger Platz 1, 13353 Berlin, Germany. ${ }^{6}$ Present address: Department of Genome Editing, Institute of Biomedical Science, Kansai Medical University, 2-5-1 Shinmachi, Hirakata, Osaka 573-1010, Japan. ${ }^{7}$ Present address: Bioinformatics and Scientific Programming Core, Eunice Kennedy Shriver National Institute of Child Health and Human Development, National Institutes of Health, Bethesda, MD 20892, USA.

Correspondence and requests for materials should be addressed to J.D. (email: jurrien.dean@nih.gov)
} 